\title{
perifèria
}

Número 11, Diciembre 2009

www.periferia.name

\section{Paranismo, movimento artístico do sul do Brasil no início do século XX}

\author{
Luis Afonso Salturi - Doutorando em Sociología, Universidade Federal do \\ Paraná (UFPR), Brasil ${ }^{1}$
}

\begin{abstract}
Resumo
Este artigo trata sobre a diferença entre os termos paranismo e Movimento Paranista, inseridos no contexto das discussões sobre o regionalismo no Estado do Paraná, sul do Brasil. O ensaio está dividido em três partes. A primeira delas analisa a importância da obra intelectual de Romário Martins (1874-1948) para a produção cultural paranaense. A segunda apresenta um balanço do desenvolvimento das artes plásticas e da música no Paraná, relacionando-as com as manifestações regionais. A última trata sobre a bibliografia existente sobre o paranismo e fornece uma nova interpretação da definição dos termos através de uma releitura da produção intelectual de Romário Martins, considerando ainda a importância da prática e da produção artística nesse contexto.
\end{abstract}

Palavras-chave: Movimento Paranista; paranismo; arte brasileira.

\begin{abstract}
This article discusses the difference between the terms paranismo and Paranista Movement, placed in the context of discussions on regionalism in the State of Paraná, in Brazil. The essay is divided into three parts. The first one examines the importance of intellectual work of Romário Martins (1874-1948) for cultural production of Paraná. The second presents a review of the development of fine arts and music in Paraná, relating them to the regional events. The latest deals on the existing literature about paranismo and provides a new interpretation of the definition of the terms through a rereading of the intellectual output of Romário Martins, considering the importance of practice and artistic production in that context.
\end{abstract}

Key words: Paranista Movement; paranismo; Brazilian Art.

\footnotetext{
${ }^{1}$ Enviar correspondencia a: lasalturi@yahoo.com.br
} 


\section{perifèria}

Número 11, Diciembre 2009

www.periferia.name

\section{I ntrodução}

Um sociólogo teria em nosso meio um campo interessantíssimo de estudos em numerosos grupos de nossa população, distintos entre si. Sem sair de Curitiba, teria a seu dispor materiais etnográficos para estudar a diversidade de usos e costumes, de temperamento e de caráter, de inteligência e de imaginação, que nos fazem a sociedade mais cosmopolita do Brasil.

Romário Martins

Essa citação, extraída de um texto do jornalista Romário Martins (1874-1948) publicado posteriormente na revista A divulgação (1948), relata sobre a necessidade de estudos de Sociologia que tivessem como objeto de análise a sociedade do Estado do Paraná, sul do Brasil. Parece que, desde aquele tempo até os dias de hoje, a ideia de se pesquisar sobre a sociedade em que viveu o referido autor não tem encantado muito aos sociólogos. Talvez isso ocorra porque esse tipo de pesquisa sociológica, na maioria das vezes, acaba ocasionando muitos entraves, devido não só ao levantamento das fontes, mas à aproximação de outras áreas do conhecimento, como a História, que em âmbito local, não possui integração acadêmica com as pesquisas desenvolvidas no âmbito das Ciências Sociais.

Frente a essas questões, levantadas já em estudo anterior (Salturi, 2007), é no domínio da Sociologia da Cultura que nasce o interesse pelos movimentos culturais desenvolvidos no Estado do Paraná. Nessa abordagem, ao se tentar entender determinada época e um grupo de determinados indivíduos que nela viveram e produziram, busca-se situá-los dentro de um contexto sociocultural, procurando compreender a integração entre eles e a dinâmica de suas ações. Assim, esse artigo tem como objetivo discutir sobre os conceitos de paranismo e de Movimento Paranista tomando como base a bibliografia existente sobre o tema. Com isso, pretende-se mostrar como o paranismo, em meados da década de 1920, se constituiu como um movimento integrado em que políticos, intelectuais e artistas envolveram-se com a questão da definição de uma identidade local. 


\section{perifèria}

Número 11, Diciembre 2009

www.periferia.name

\section{A obra histórica e literária de Romário Martins}

Ao tratar sobre a obra produzida por Romário Martins, um dos intelectuais paranaenses mais importantes do início do século XX, torna-se necessário analisar sua biografia. Para a realização dessa tarefa, toma-se como referencial teórico a crítica de Bourdieu (2004) sobre as histórias de vida, presente em A ilusão biográfica, e a perspectiva do "eu" no estudo de trajetórias sociais, conforme mostra Elias (1995) em seu estudo monográfico sobre Mozart. Dessa forma, a abordagem proposta permite compreender a atuação de Romário Martins nos campos político e cultural do Paraná no período em questão.

Nascido em Curitiba, em 1874, Alfredo Romário Martins era filho do tenente-coronel José Antonio Martins e de Florência Severina Ferreira. Seu pai morreu quando Romário tinha apenas dez anos e, com isso, sua família acabou empobrecendo. Sem condições financeiras para fazer curso superior, sua formação se deu através de leituras, pesquisas e debates com outros intelectuais. Em 1889, iniciou-se como auxiliar de tipógrafo no jornal Dezenove de Dezembro e, no mesmo ano, passou à redação como jornalista e redator-chefe no jornal A República. Ao longo de sua carreira, Romário exerceu diversos cargos políticos, como os de Deputado Estadual, de Vereador e de Presidente da Câmara Municipal de Curitiba. Em momentos distintos, foi também Agente do Arquivo Público, Delegado Fiscal do Governo junto ao Ginásio Paranaense e diretor do Departamento Estadual de Agricultura e do Museu Paranaense.

Romário Martins influenciou vários intelectuais e artistas de sua época. Ao longo de sua trajetória, empenhou-se na divulgação da história e do folclore do Paraná, sendo um dos fundadores do Instituto Histórico e Geográfico do Paraná, criado em 1900, e principal fundador do Centro Paranista, criado em 1927. Dedicou-se à pesquisa documental sobre a questão dos limites entre os Estados do Paraná e de Santa Catarina e elaborou algumas leis, dentre elas, a da criação da Bandeira e do Brasão do Estado do Paraná e a da proposta da data de 29 de março para o aniversário da cidade de Curitiba, capital do referido Estado. Romário construiu símbolos representativos da memória coletiva que identificavam e diferenciavam o 


\section{perifèria}

Número 11, Diciembre 2009

www.periferia. name

Paraná do resto do Brasil. Essa construção simbólica não só diz respeito à representação do ideal de progresso da civilização do Estado, como ganha sentido quando relacionado com alguns dos seus escritos históricos e literários, nos quais o autor tenta resgatar o ponto inicial da história paranaense.

Essa preocupação está presente em vários dos seus trabalhos, como em Curityba: estudo onomástico (Martins, 1926). Obra em que fala sobre a colonização de Curitiba e comenta sobre as diferentes grafias feitas por aqueles que referenciaram essa região em documentos oficiais e não-oficiais. Nela, o autor faz uma análise do prefixo e do sufixo que compõem a palavra Curitiba e seus diferentes significados. Segundo ele, o nome da capital paranaense se compõe de duas palavras dissilábicas da língua geral ou abaneeng: Cury, pinhão, árvore do pinhão, pinheiro; e Tyba, muito, abundância. Portanto, Curitiba se traduziria como pinhal ou pinheiral. Na obra citada, tal definição é posta à prova quando o autor comenta sobre as análises de vários estudiosos que concordam ou discordam desta interpretação.

Nessa obra, Romário também trata da versão caingangue do termo, narrando uma lenda dessa tribo indígena que explica a escolha do nome Curi-Tim para a região que daria origem à cidade de Curitiba, através de uma alteração portuguesa tanto da escrita quanto do significado. Essa lenda, repassada de geração em geração através da tradição oral, foi narrada pelo falecido cacique Paulino Arakchó, amigo de Telêmaco Borba, que segundo Romário Martins, é o verdadeiro autor da narrativa escrita. Nesse ponto, é visível a influência do romantismo indianista do século XIX na produção histórica e literária de Romário, que iniciou sua atividade intelectual num ambiente ainda influenciado pela presença do Movimento Simbolista no Paraná e pelo pensamento positivista que promoveu a República no Brasil.

No que diz respeito à historiografia, grande parte da produção intelectual de Romário Martins tem perdido sua importância, principalmente porque alguns autores tomam sua obra como alegoria, numa perspectiva benjaminiana em que a "dominação do imaginário popular" se torna o ponto de partida para a análise (Benjamin, 1994). Um exemplo dessa perspectiva é o trabalho de Szvarça (1993) 


\section{perifèria}

Número 11, Diciembre 2009

www.periferia.name

que faz referência a Romário Martins como um "historiador historicista", um "forjador" de símbolos. Para o autor, a história produzida por Romário, em termos benjaminianos, é um exemplo da "história dos dominadores", que é descontínua, mas apresentada como contínua num "tempo homogêneo e vazio". Nessa visão, para preencher esse tempo, Romário teria "forjado" um "conjunto de símbolos e mitos" que possibilitariam construir uma imagem da identidade ideal a qual todos deveriam integrar-se para atingir o progresso.

Szvarça está preocupado com a análise da historiografia de Romário Martins, mas ao voltar-se para as intenções de Romário em seu ofício, acaba centrando sua análise na perspectiva do "ele", da qual fala Norbert Elias. Para Elias (1995) o curso da vida de cada indivíduo é condicionado pelos seus desejos. Dessa maneira, a partir da perspectiva do "ele" não se pode determinar o que alguém sente quando satisfaz esses desejos. Deve-se entendê-lo a partir do ponto de vista da primeira pessoa, ou seja, da perspectiva do "eu", já que a vida só faz sentido para os indivíduos quando eles conseguem realizar tais aspirações. Antes de tudo, é preciso lembrar que Romário Martins tinha o paranismo como um projeto de vida. Sua produção intelectual não pode ser vista apenas pelo ângulo da "dominação do imaginário popular", propõe-se pensá-la também em relação aos seus desejos individuais.

Outra questão que deve ser mencionada são os diferentes pontos de vista em relação à origem dos mitos e lendas indígenas referenciados por Romário Martins em seus escritos. Alguns estudos históricos e ensaios jornalísticos consideram que esses mitos, entre eles o do cacique Guairacá (Martins, 1941), foram criados por Romário sem nenhuma base real. Costa (1986), por exemplo, falou durante sua participação num debate numa TV local, em 1986, sobre uma campanha de visava erguer um monumento para o lendário cacique, tido como símbolo de defesa da terra paranaense. Nessa época havia um questionamento sobre a existência do personagem, uma vez que não existiam provas documentais. 


\section{perifèria}

Número 11, Diciembre 2009

www.periferia.name

Os estudos históricos que tratam sobre os escritos de Romário Martins dizem que os mitos e lendas que aparecem nas obras deste foram criados pelo próprio autor com o intuito de atingir o "imaginário popular" para garantir a "dominação". Num depoimento para Prosser (2004: 153), Adalice Araujo, pesquisadora e crítica de arte renomada, diz que essas pesquisas são "totalmente políticas e inverossímeis". Para ela, mitos, como o do Guairacá, têm mesmo uma base real, porque remetem à tradição dos índios. Isto porque, segundo ela, uma das características do paranismo é a defesa da causa indígena. Considerando esses dois pontos de vista divergentes e os limites do presente artigo, esse debate só poderia ser esclarecido com mais pesquisas sobre o tema. Contudo, para a análise proposta, o conhecimento do uso dos mitos e lendas na obra romariana já basta, sendo a questão da autoria da criação destes de menor importância.

Tendo isso em vista, em Paiquerê: mitos e lendas: visões e aspectos, Martins (1940) relata mitos e lendas dos povos indígenas do Paraná e apresenta alguns ensaios (e até uma peça teatral) que falam sobre a História do Paraná. Tomando como base a discussão teórica feita pelos estudos históricos, os mitos e lendas presentes nessa obra de Martins fazem mesmo uma ligação artificial entre o presente e um passado heróico, dentro de uma temática voltada para a identidade regional. Contudo, não há dúvidas de que os escritos de Romário exigiram dele tanto o conhecimento da História quanto da cultura indígena da região, o que não pode ser tratado apenas como uma invenção a partir do nada.

A questão da identidade local é tratada também no artigo Paranística, no qual Romário apresenta a definição de paranismo e o significado do termo paranista. A esse respeito, o depoimento do autor é de que o vocábulo paranista foi utilizado pela primeira vez, em 1906, pelo escritor Domingos Nascimento após regressar de uma viagem ao norte do Paraná, onde notara que ninguém o chamava de paranaense, mas de paranista. Essa palavra teria nascido espontaneamente, e ganharia uma nova significação por Romário, já que, em 1927, o mesmo se pôs à frente de um movimento por uma acepção nova do termo, criando em Curitiba o Centro Paranista. A partir dessa definição, é possível compreender quais eram os propósitos do movimento de mesmo nome, pois para o autor: 


\section{perifèria}

Número 11, Diciembre 2009

www. periferia.name

Paranismo é todo aquêle que tem pelo Paraná uma afeição sincera, e que notàvelmente a demonstra em qualquer manifestação de atividade digna, útil à coletividade paranaense. (...) Paranista é simbólicamente aquele que em terra do Paraná lavrou um campo, vadeou uma floresta, lançou uma ponte, construiu uma máquina, dirigiu uma fábrica, compoz uma estrofe, pintou um quadro, esculpiu uma estátua, redigiu uma lei liberal, praticou a bondade, iluminou um cérebro, evitou uma injustiça, educou um sentimento, reformou um perverso, escreveu um livro, plantou uma árvore. Paranismo é o espírito novo, de elação e exaltação, idealizador de um Paraná maior e melhor pelo trabalho, pela ordem, pelo progresso, pela bondade, pela justiça, pela cultura, pela civilização. É o ambiente de paz e solidariedade, o brilho e a altura dos ideais, as realizações superiores da inteligência e dos sentimentos. (Martins, 1948: 38)

Ainda sobre essa questão, é preciso verificar os diferentes significados do termo paranista ao longo dos anos. Segundo Trevisan (1991: 23), antes de ser apropriado por Romário Martins, esse termo aparecia no livro Os caboclos, de Valdomiro Silveira. No vocabulário, ao final da obra citada, aparece a definição de paranista como: "o natural do Estado do Paraná" (Silveira, 1975: 152). Este seria, então, um dos registros impressos mais antigos do vocábulo, já que todos os contos desse livro foram escritos entre 1897 e 1906. Contudo, a definição do termo paranista não é a única que merece importância. É preciso também esclarecer a diferença entre os termos paranismo e Movimento Paranista, pois ainda hoje alguns autores falam em paranismo, mas não se referem ao Movimento Paranista. Para salientar a importância dessa diferenciação, passa-se agora à análise do processo que levou à constituição desse movimento.

\section{O paranismo nas artes}

Nas artes plásticas, a adesão ao paranismo aconteceu em meados da década de 1920, devido principalmente às influências das correntes de pensamento de alguns intelectuais da época, em especial, Romário Martins. Naquele período, a literatura ainda mantinha algumas características simbolistas e os estudos históricos e 


\section{perifèria}

Número 11, Diciembre 2009

www.periferia.name

políticos estavam concentrados em questões regionais. Desse modo, tanto a literatura quanto os estudos históricos e políticos tiveram um papel fundamental no processo de migração do paranismo, enquanto ideal, dessas áreas para as artes.

Vale lembrar que a profissionalização artística no Paraná e a consolidação desse campo tiveram início com o pioneirismo de dois artistas-professores estrangeiros que se radicaram na região. Enquanto a Escola de Belas Artes e Indústrias, criada pelo português Mariano de Lima, foi responsável por colocar o Paraná na vanguarda brasileira no ensino voltado para as artes, no caso específico da pintura, foi com Alfredo Andersen que surgiu uma verdadeira escola voltada para essa atividade.

Na Curitiba do início do século $X X$ era comum que os alunos dessas primeiras escolas de arte fossem indicados por seus professores para receberem bolsas de estudo do Governo do Estado para auxílio financeiro durante o período de formação no exterior. Assim, Frederico Lange de Morretes, João Turin e Zaco Paraná, principais representantes do paranismo nas artes visuais, pertencem à primeira geração de artistas paranaenses que fizeram cursos de aprimoramento na Europa. Com o regresso dessa primeira geração, o interesse pela arte no Estado viria a aumentar. Além disso, antes da década de 1920, segundo De Bona (2004: 28-29), J oão Ghefi e seus amigos já haviam dado início à vida boêmia dos artistas locais ao instalar seu atelier na Rua Marechal Deodoro, local que se transformou em ponto de encontro dos jovens intelectuais e artistas que debatiam especialmente sobre as artes.

Nesse cenário, a crítica de arte ganhava maior espaço nas revistas e nos jornais locais, contribuindo ainda mais para que esses artistas fossem descobertos e valorizados pelo público. Algumas vezes os próprios artistas usavam pseudônimos ao escreverem sobre seus colegas, como no caso de Ghelfi que utilizou o nome Ghibellinus para fazer uma crítica exaltando Lange de Morretes (Guibellinus, 1920). Em outras ocasiões, mas não com fins diferentes, as críticas de arte eram sustentadas por amigos dos artistas, como no caso dos escritos do jornalista Samuel Cesar sobre João Ghelfi, Lange de Morretes, João Turin e Zaco Paraná. (Cesar, 1923, 1928, 1930a, 1930b, 1930c). 


\section{perifèria}

Número 11, Diciembre 2009

\section{www. periferia. name}

Nas artes visuais, a sociabilidade entre esses artistas contribuiu significativamente para o surgimento do paranismo como vertente de expressão artística, manifestando-se através da representação de temas locais da flora, da fauna e do indígena, tanto nas artes plásticas, quanto nas artes gráficas e decorativas. Em 1923, num dos diversos encontros entre Lange de Morretes, Ghelfi e Turin, após vários estudos, esses artistas criaram uma fórmula geométrica para a representação do pinhão, semente do pinheiro, árvore considerada símbolo do Estado do Paraná (figura 1).

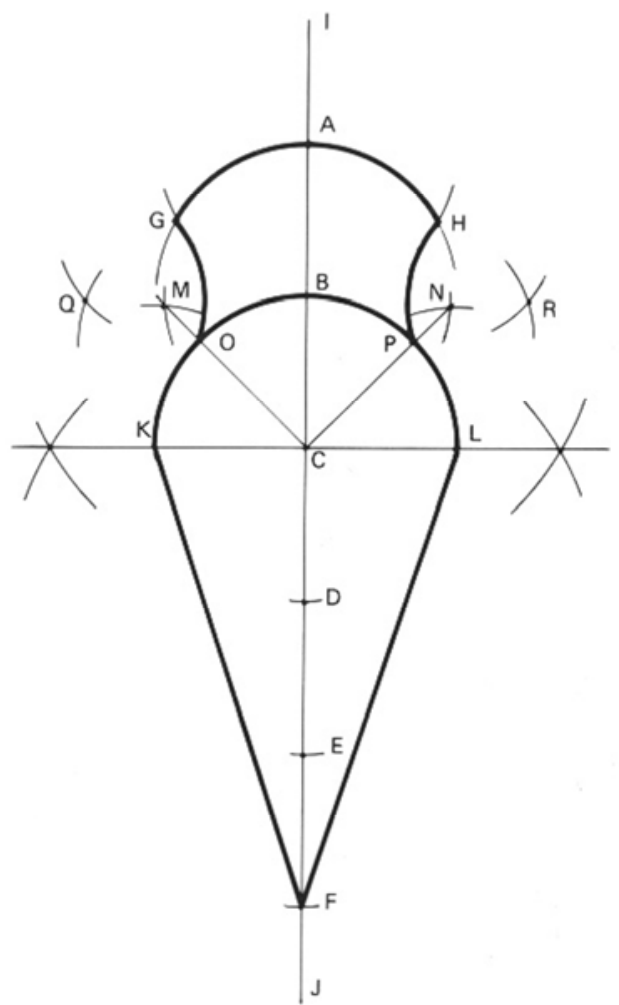

Figura 1. Morretes, F. L. de. Pinhão geométrico. In: Hoerner Jr. (1992: 43)

A fórmula geométrica do pinhão daria origem à estilização paranaense ou paranista (figura 2) que, como elemento decorativo, teria aplicação em revistas, móveis, molduras e em capitéis e adornos arquitetônicos. Assim, Lange de Morretes, Ghelfi e Turin tornaram conhecida uma arte decorativa baseada no pinheiro, pinha e pinhões e em outros elementos da natureza do Paraná. Essas representações 


\section{perifèria}

Número 11, Diciembre 2009

www. periferia. name

também se deram através de projetos e obras de pintura, desenho, escultura, artes gráficas, arquitetura e design de moda, mantendo diálogo com os estilos e as linguagens dos movimentos artísticos europeus.
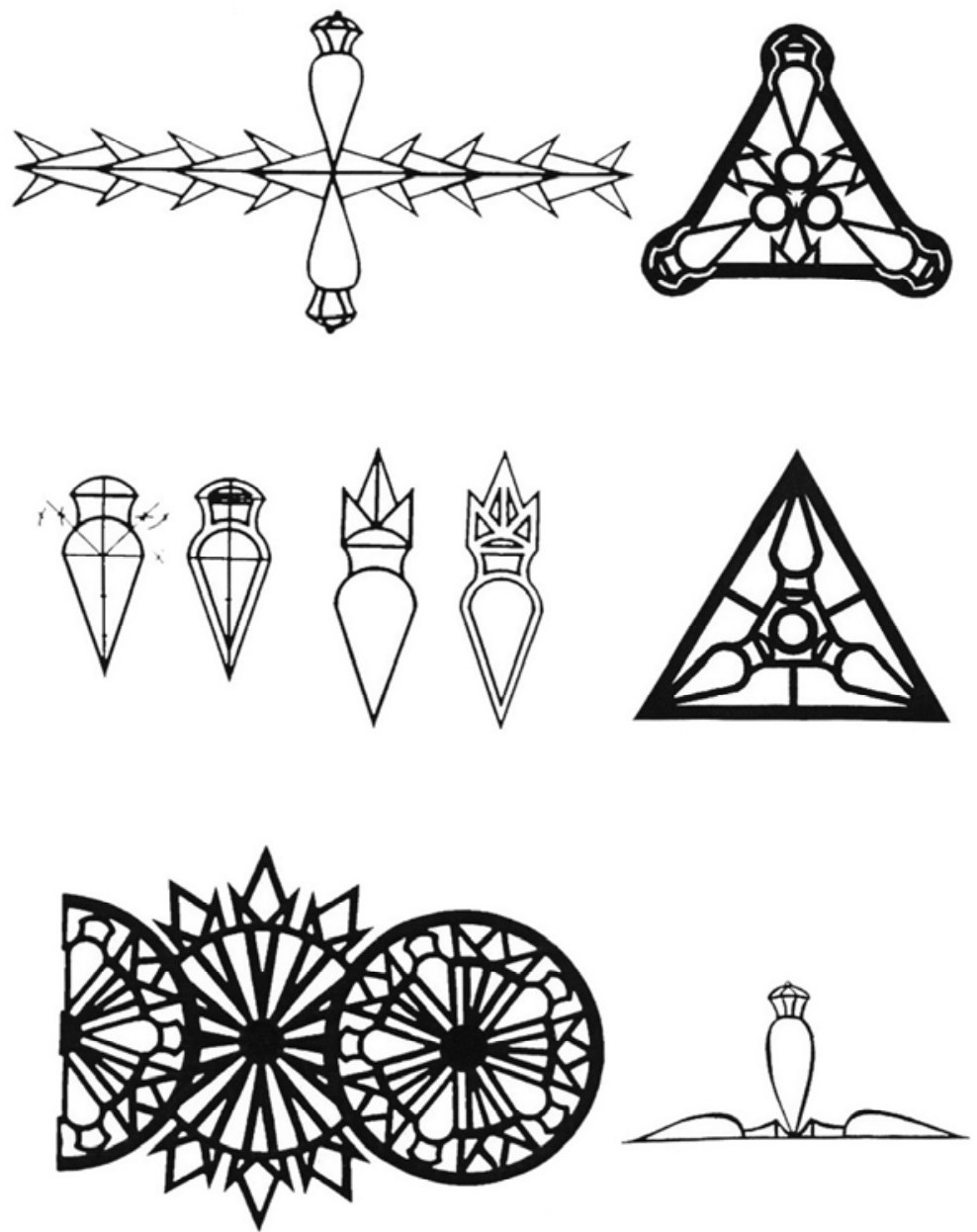

Figura 2. Morretes, F. L. de. Estilização do pinheiro, pinha e pinhões. In: Morretes (1953: 168-169)

O escultor João Turin elaborou diversos projetos arquitetônicos com uma grande variedade de desenhos de capitéis com motivos de pinheiro. Devido à falta de arquitetos que aderissem à proposta, muitos desses projetos ficaram apenas no papel e acabaram se perdendo com o tempo. Além do pinheiro, outros elementos da flora e fauna paranaense faziam parte da estilização paranista, entre os quais a 


\section{perifèria}

Número 11, Diciembre 2009

www. periferia. name

palmeira, a guabiroba, a pitanga, o maracujá, o café, a erva-mate e também a gralha-azul e os índios da região. Em relação a estes últimos, as representações das lendas e mitos indígenas aparecem em várias esculturas, alto relevos e desenhos do artista, como pode ser visto nesses dois trabalhos (figuras 3 e 4).

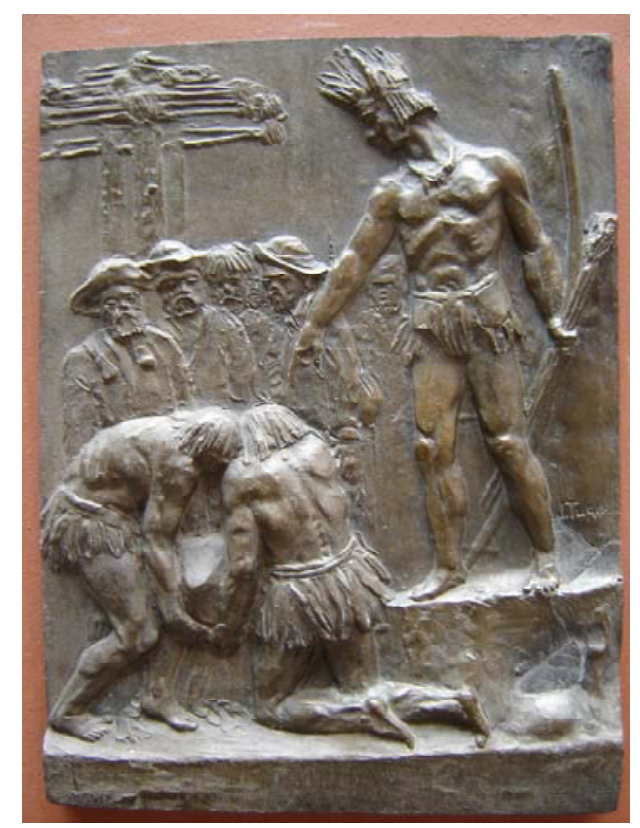

Figura 3. Turin, J. Fundação de Curitiba. 1943. Baixo relevo em bronze. Memorial de Curitiba. Foto: Luis Afonso Salturi. 


\section{perifèria}

Número 11, Diciembre 2009

www. periferia. name

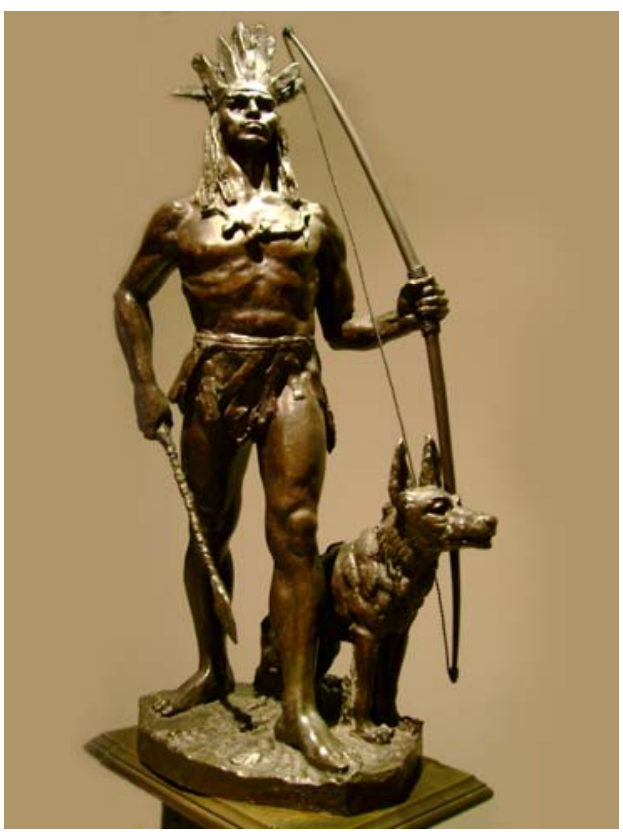

Figura 4. Turin, J. Guairacá. Sem data. Escultura. $117,5 \times 71,4 \times 35,5 \mathrm{~cm}$. Museu Oscar Niemeyer, Curitiba. Foto: Luis Afonso Salturi.

As referências teóricas e as ideias que levaram esses artistas a produzirem esse tipo de arte aparecem em alguns escritos divulgados posteriormente, como $\mathrm{O}$ pinheiro na Arte, Um pedaço do Brasil e Erna e Maria Aparecida, de Lange de Morretes (Morretes, 1937, 1948, 1953), e A arte decorativa no Brasil, de João Turin (Turin, 19--). Num deles, Morretes (1948), ao comentar sobre as idealizações das telas Alma da Floresta (figura 5) e A Natureza (figura 6), acaba mostrando sua independência no processo criativo de suas pinturas, o que representa apenas um exemplo dos fatos que contrariam vários estudos sobre o paranismo que concebem em suas análises uma submissão total do campo artístico ao campo político. 


\section{perifèria}

Número 11, Diciembre 2009

www. periferia. name

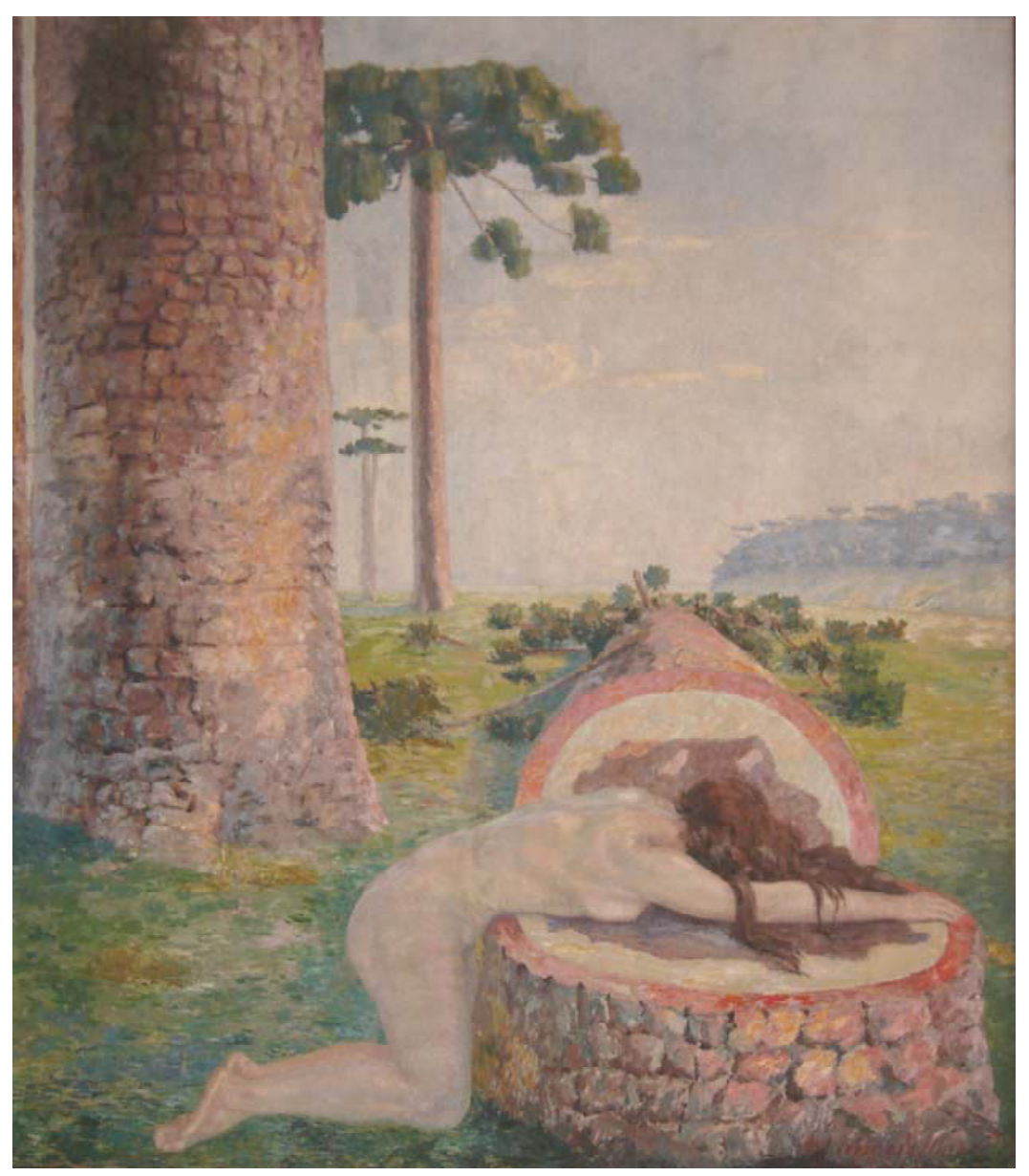

Figura 5. Morretes, F. L. de. Alma da Floresta. 1927-1930. Óleo sobre tela: color; 285 x 245 cm. Assembléia Legislativa do Paraná, Curitiba. Foto: Luis Afonso Salturi. 


\section{perifèria}

Número 11, Diciembre 2009

www. periferia. name

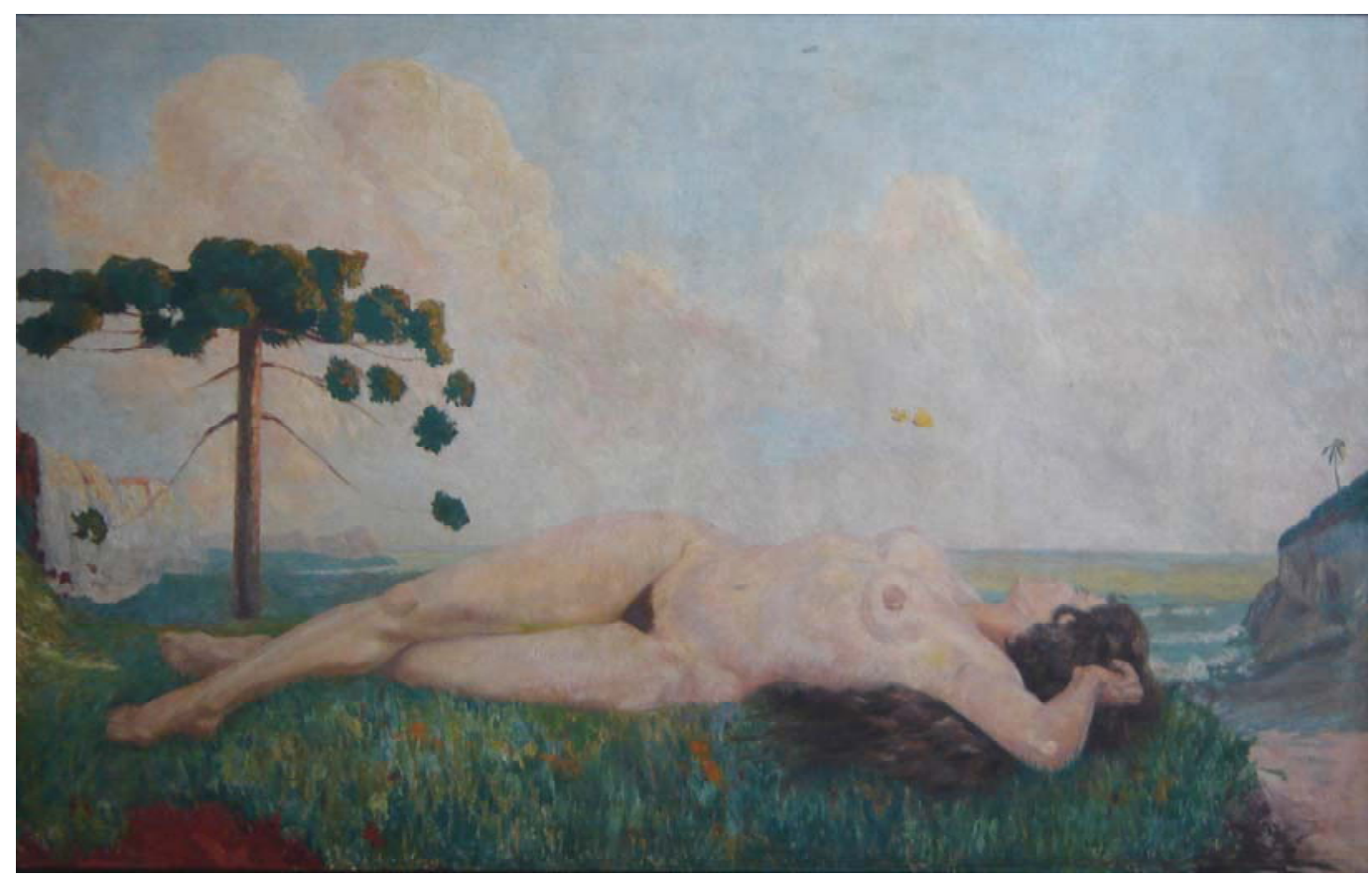

Figura 6. Morretes, F. L. de. A Natureza. Sem data. Óleo sobre tela: color.; 145 x $288 \mathrm{~cm}$. Escola de Música e Belas Artes do Paraná, Curitiba. Foto: Luis Afonso Salturi.

Na música e no teatro, o paranismo se manifestou em motivos musicais baseados em canções tradicionais ou em gêneros populares com textos exaltando temas locais nas composições. Um dos poucos estudos sobre o assunto é o artigo de Roderjan (1969), no qual a autora ressalta que a década de 1930 tem como marca o cultivo de tudo aquilo que faz referência ao Paraná, através do paranismo de Romário Martins, que valorizava as lendas indígenas. Essas serviam de inspiração para vários artistas, como Romualdo Suriani, que escreveu um poema sinfônico sobre a terra paranaense chamado Gôio-Covó, nome que os índios caingangues davam ao Rio Iguaçu.

Entre 1927 e 1930, o Movimento Paranista vivenciou o seu auge, atingindo as artes plásticas e musicais, passando por um período em que seus ideais estavam organizados e institucionalizados em forma de práticas culturais. O melhor exemplo disso é a revista Illustração Paranaense, criada em 1927, pelo fotógrafo e jornalista J oão Baptista Groff. O periódico refletia os temas e o ideário em voga naquele 


\section{perifèria}

Número 11, Diciembre 2009

www. periferia. name

momento, tinha uma ótima qualidade gráfica e editorial e contava com a colaboração de artistas e intelectuais. Até mesmo a capa da revista (figura 7 ), de autoria de João Turin, apresenta um tema com forte referência nas lendas indígenas dos escritos de Romário Martins. Tendo circulado com grande freqüência até 1930, a revista interrompeu sua publicação em decorrência da crise gerada pela Revolução de 1930.

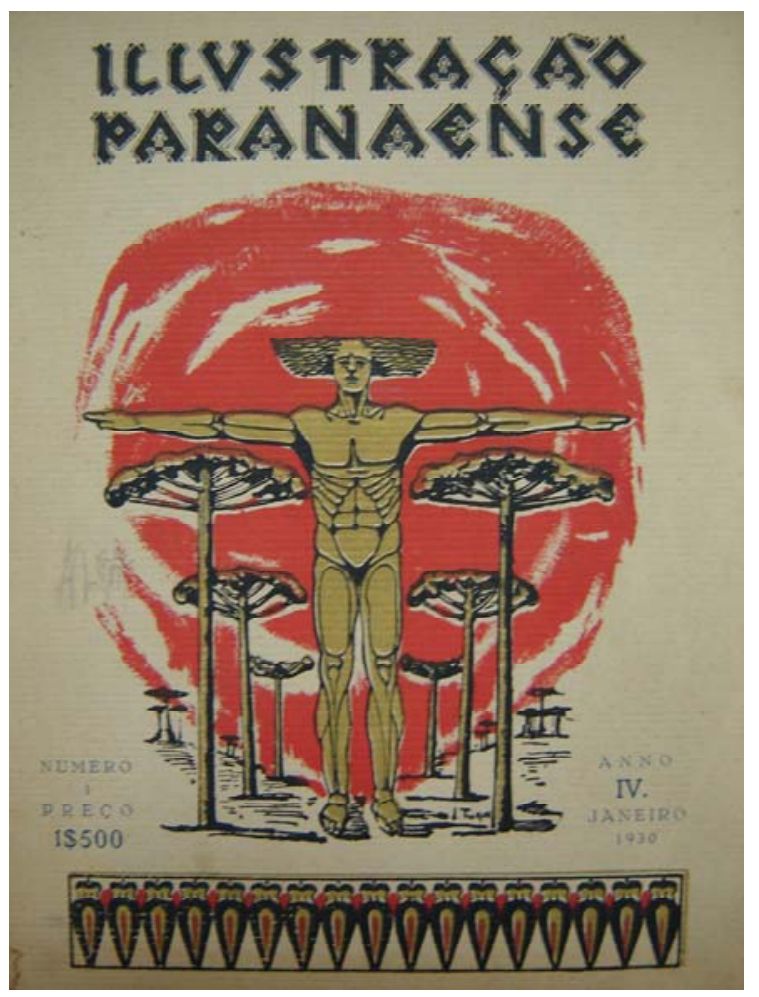

Figura 7. Turin, J. Homem-pinheiro. Capa da revista Illustração Paranaense: Mensário paranista de arte e actualidades. Curitiba, Ano IV, n. 1, jan. 1930. Foto: Luis Afonso Salturi.

\section{Os conceitos de paranismo e de Movimento Paranista}

Em Regionalismo e Anti-regionalismo no Paraná, um dos primeiros trabalhos acadêmicos sobre o paranismo, Keinert (1978) situa o regionalismo globalmente, critica outras análises feitas sobre essa temática até aquele momento e estabelece um critério de classificação para o caso paranaense. Para o autor, o regionalismo 


\section{perifèria}

Número 11, Diciembre 2009

www.periferia.name

no Paraná assumiu diferentes características. Durante o Estado Novo, foi influenciado pelo paranismo e após 1945 foi marcado por diferentes nuances. Esse autor vê o paranismo como a matriz da manifestação do regionalismo no Paraná, uma "postulação básica" que foi retomada a partir da década de 1930. Para ele, os "sentimentos regionalistas paranaenses" foram reatualizados nas configurações ideológicas que se formaram em seguida.

Em seu trabalho, Keinert adota como recurso teórico-metodológico o conceito de formação regional e as concepções de dominação e ideologia. Para o autor, a dominação se limita a garantir a reprodução de interesses dominantes através do controle do aparelho jurídico-político do Estado. Assim, ele trata o paranismo como um movimento ideológico que se constituiu num "símile regional comedido do ufanismo nacional" e que alcançou vários outros campos de manifestação simbólica ao extravasar os estudos políticos e históricos. O autor diz que foram esses estudos que deram início ao paranismo e destaca a ação dos principais fundamentadores: Ermelino Agostinho de Leão, Francisco Negrão e Romário Martins. Nesse ponto, o autor dá ênfase aos estudos desenvolvidos por esses intelectuais, caracterizando-os a partir das preocupações temáticas de cada um, ligadas à questão dos limites geográficos do Paraná e à propaganda política do Estado.

Esse trabalho mencionado pode ser visto como um exemplo da visão dos estudos sócio-políticos e econômicos sobre o regionalismo que tratam esse como sinônimo de classes dominantes, tomando o paranismo como uma ideologia das elites políticas locais. Nessa visão, o paranismo e o Movimento Paranista são tratados como sinônimos, na medida em que o autor considera o que no seu caso seria o Movimento Paranista como uma pré-fase do desenvolvimento do regionalismo no Paraná, que é chamada por ele de paranismo.

Em Paranismo: cultura e imaginário no Paraná da I República, Pereira (1997) comenta sobre três recortes analíticos acerca da temática do paranismo. O primeiro, ao privilegiar a análise das elites locais, a transforma em tema passando então a vê-la como elemento modernizador. O segundo, ao privilegiar a análise das oligarquias, considera o período da República Velha como uma fase de transição de regimes políticos, devido à crise de legitimidade e eficiência do governo. Para esse 


\section{perifèria}

Número 11, Diciembre 2009

www.periferia.name

autor, ambos recortes confundem regionalismo com classes dominantes, acabando por fazer uma história das oligarquias e das elites locais. Já o terceiro recorte, influenciado pelo marxismo, enfatiza o desenvolvimento global do capitalismo buscando traços intrínsecos a cada região, onde a proposta de estabelecer uma identidade regional passa a ser vista como produto ideológico das classes dominantes nos estados, e ao fazer isso estabelece uma redução da arte e um esquecimento da questão cultural.

$\mathrm{Na}$ tentativa de fazer uma análise diferente desses recortes, o autor rastreia o regionalismo no Paraná buscando-o não apenas em questões tradicionais como a Federação ou o papel das elites locais e a dinâmica global do capitalismo. Ele mostra como se deu o processo de construção da identidade local nas particularidades do Paraná, não apenas na relação periférica do Estado com o governo central, mas em seu republicanismo positivista e anticlerical, na ideia de modernidade que se tinha e se divulgava, e nas questões culturais cujos mitos e símbolos tiveram papel importante para a "dominação do imaginário popular".

Apesar disso, do mesmo modo que os autores anteriormente citados, Pereira não se preocupou em distinguir o paranismo do Movimento Paranista. Como seu trabalho está voltado para a construção da historiografia, ao investir na questão da "dominação do imaginário popular" pelos paranistas, algumas de suas análises acabaram sendo marcadas por certo pessimismo. Esse pessimismo aparece possivelmente devido aos modelos teóricos adotados não só por ele, mas por outros historiadores, como a crítica benjaminiana à construção da História e a aplicação ao caso paranaense do conceito de tradição inventada (Hobsbawm, 1997). Esses modelos teóricos servem como instrumentos de análise para a construção da historiografia e a questão da dominação, mas são insuficientes para compreender o que se pode chamar, em termos dessas próprias leituras, de "ponto de vista do dominador", ou ainda, a perspectiva do "eu", da qual fala Elias (1995).

Os estudos de História sobre o paranismo acertam em afirmar que, de modo geral, a história criada pelos paranistas privilegiava os símbolos oficiais do Estado do Paraná e o folclore local, tendo ainda uma forte ligação com uma literatura que fazia referência à cultura indígena. A literatura produzida pelos paranistas, em 


\section{perifèria}

Número 11, Diciembre 2009

www.periferia.name

especial por Romário Martins, fazia mesmo uma ligação artificial entre o presente e o passado dentro de uma temática que visava definir o paranaense. Contudo, os estudos históricos privilegiam em suas análises apenas a "dominação do imaginário popular" ao invés de tentar entender o que levou os paranistas a "dominarem esse imaginário" ou "formarem almas" - utilizando o termo de Carvalho (1990).

$\mathrm{Na}$ análise dos estudos históricos que tratam sobre a historiografia de Romário Martins, há de se considerar que, enquanto produtos culturais, esses estudos são marcados pelo período em que foram feitos. Durante a década de 1990, a crítica benjaminiana da História influenciou várias pesquisas com a temática do Paraná. Partindo dela, ao invés de tentar compreender o pensamento de Romário Martins, os historiadores o enxergavam de uma maneira muito pessimista. Eles reduziam sua figura e desconstruíam seu discurso histórico, que era voltado tanto para os documentos oficiais quanto para os interesses da elite econômica local. Nesses trabalhos, nota-se também uma preocupação constante em discutir sobre a continuidade do ideal paranista nos escritos de Wilson Martins e Temístocles Linhares, escritores consagrados, cujos estudos, segundo os historiadores, ainda carregariam uma "visão paranista", principalmente no que se refere à identidade do Paraná. Sobre esse ponto, é óbvio que os historiadores estão voltados para a construção da História, mas aqui, a crítica está mais para uma disputa pelo pólo dominante desse campo, o da produção de estudos históricos, do que propriamente uma revisão da historiografia local. A esse respeito, vale citar os apontamentos de autores como Bourdieu (1996, 2004), de que as obras culturais e científicas trazem consigo as marcas não só do momento em que foram produzidas como também do próprio campo de que são produto.

Além desses trabalhos, é preciso apontar outra bibliografia que trata do paranismo, apresentada em artigos de linguagem econômica ou jornalística, como Costa (1984 e 1991) e Leão (1999). Esses trabalhos mostram não só o reducionismo e a existência de diferentes abordagens sobre a temática do paranismo, mas também os múltiplos significados do termo, que é utilizado para análise de diferentes épocas e contextos, sejam eles culturais políticos ou econômicos. A ideia de paranismo desses autores não condiz com a de outros para os quais o termo paranismo é tido 


\section{perifèria}

Número 11, Diciembre 2009

www.periferia.name

como sinônimo de Movimento Paranista. Daí, portanto, o motivo desta crítica, pois essas discussões não mantêm um consenso sobre o que é paranismo e o que foi o Movimento Paranista.

Resgatando o uso feito por Romário Martins, o paranismo pode ser compreendido como um sentimento ligado a um ideal, uma "forma de pensar" o Paraná relacionado à identidade local, seja ela na esfera política, econômica ou cultural, com vistas a um futuro próspero, rumo ao progresso. Nesse ponto, consideram-se as questões ideológicas presentes nessa definição, mas sem fazer sobre elas juízo de valor, o que permite resgatar o sentido original que a mesma tinha para seu autor e que direcionava suas ações. Já o Movimento Paranista, foi uma maneira de colocar em prática esse sentimento, essa "forma de pensar" que, só atingiu o caráter de movimento em meados da década de 1920. Assim como todo o movimento, o Movimento Paranista é datado, na medida em que é envolvido pela ação de um grupo de certos indivíduos. Nesse sentido, é objetivo. Diferentemente, o paranismo, enquanto um sentimento, não é datado, é subjetivo, ele continuou associado às outras ideologias que surgiram no Paraná em períodos subseqüentes e ainda hoje, visto assim, ele ainda persiste.

\section{Bibliografia}

Benjamin, Walter (1994). Magia e técnica, arte e política: ensaios sobre literatura e história da cultura. Obras Escolhidas Vol. 1. 7 ed. São Paulo: Brasiliense, pp. 222232.

Bourdieu, Pierre (1996). As regras da arte: gênese e estrutura do campo literário. São Paulo: Companhia das Letras.

(2004). Razões práticas: sobre a teoria da ação. 5 ed. Campinas: Papirus.

Carvalho, José Murilo de (1990). A formação das almas: o imaginário da República no Brasil. São Paulo: Companhia das Letras.

Cesar, Samuel (1923). "Quatro artistas novos: João Turin, Esculptor; Lange de Morretes, Pintor; Zaco Paraná, Esculptor; J. Ghelfi, Pintor". In: Album da Gazeta do Povo. Curitiba, dez. pp. 9-17. 


\section{perifèria}

Número 11, Diciembre 2009

www.periferia.name

(1928). "Dois artistas brasileiros: Lange e Turin". Illustração Paranaense: Mensário paranista de arte e actualidades. Curitiba, Ano II, n. 10-11, out./nov.

(1930a). "Lange de Morretes". Illustração Paranaense: Mensário paranista de arte e actualidades. Curitiba, Ano IV, n. 6, jun.

(1930b). "Um grande artista: Lange de Morretes". Diário da Tarde, Curitiba, 12 maio, p. 2.

(1930c). "Um grande desventurado: J. Ghelfi". Toda Tarde. Diário da Tarde, Curitiba, 19 de maio.

Costa, Samuel Guimarães da (1984). "Uma sociologia do paranismo". Gazeta do Povo, Curitiba, 27 maio.

(1986). "Guairacá: um falso mito paranista". Gazeta do Povo, Curitiba, 15 abr.

(1991). "Alienação do paranismo". Gazeta do Povo, Curitiba, 13 ago.

De Bona, Theodoro (2004). Curitiba, Pequena Montparnasse. Curitiba: Secretaria do Estado da Cultura.

Elias, Norbert (1995). Mozart, sociologia de um gênio. Rio de Janeiro: Jorge Zahar.

Guibellinus (1920). "Um pintor: Frederico Lange de Morretes". Commercio do Paraná, Curitiba, 30 jun, pp. 2.

Hobsbawm, Eric (1997). "Introdução: A invenção das tradições". In: Ranger, Terence. (orgs.) A invenção das tradições. Rio de Janeiro: Paz e Terra, pp. 9-23.

Hoerner J r., Valério (1992). Pinheirismo: emoção e querência, Luís Pilotto. Curitiba: Champagnat.

Keinert, Ruben César (1978). Regionalismo e anti-regionalismo no Paraná. São Paulo. Dissertação (Mestrado em Sociologia) - Faculdade de Filosofia, Letras e Ciências Humanas, Universidade de São Paulo.

Leão, Igor Zanoni C. Carneiro (1999). "As desventuras do paranismo". Revista FAE. 


\section{perifèria}

Número 11, Diciembre 2009

www.periferia.name

Curitiba, v. 2, n. 3, set./dez., pp. 9-20.

Martins, Romário (1926). Curityba: estudo onomástico. Curitiba: Livraria Mundial \& Cia.

(1940). Paiquerê: mitos e lendas, visões e aspectos. Curitiba: Guaíra.

(1941). Guairacá: movimento nacional pró-monumento a Guairacá. Curitiba:

Empresa Gráfica Paranaense.

(1948). "Paranística". A divulgação, Curitiba, Ano I, n. 3-4, pp. 37-39,

fev./mar.

Morretes, Frederico Lange de (1937). Um pedaço do Brasil. Datilografado.

(1948). Erna e Maria Aparecida: duas mulheres que encontrei no caminho da minha vida. Datilografado.

(1953). "O pinheiro na arte. Ilustração Brasileira", Ed. Comemorativa do Centenário do Paraná. Rio de Janeiro, ano XLIV, n. 224, pp. 168, 169, 274, dez.

Pereira, Luis Fernando Lopes (1997). Paranismo: o Paraná inventado; cultura e imaginário no Paraná da I República. Curitiba: Aos Quatro Ventos.

Prosser, Elisabeth Seraphim (2004). Cem anos de sociedade, arte e educação em Curitiba: 1853-1953: da Escola de Belas Artes e Indústrias de Mariano de Lima à Universidade Federal do Paraná e a Escola de Música e Belas Artes do Paraná. Coleção Páginas Escolhidas. Curitiba: Imprensa Oficial.

Roderjan, Roselys Vellozo (1969). "Aspectos da música no Paraná". In: História do Paraná. Vol. 3. Curitiba: Grafipar, pp. 171-205.

Salturi, Luis Afonso (2007). Frederico Lange de Morretes, liberdade dentro de limites: trajetória do artista-cientista. Curitiba. Dissertação (Mestrado em Sociologia) - Setor de Ciências Humanas, Letras e Artes, Universidade Federal do Paraná.

Silveira, Valdomiro (1975). Os caboclos. 4 ed. Rio de Janeiro: Civilização Brasileira. Szvarça, Décio Roberto (1993). O forjador: ruínas de um mito - Romário Martins: 


\section{perifèria}

Número 11, Diciembre 2009

www.periferia. name

1893-1944. Curitiba. Dissertação (Mestrado em História) - Setor de Ciências Humanas, Letras e Artes, Universidade Federal do Paraná.

Trevisan, Edilberto (1991). "As nascentes do paranismo". Gazeta do Povo, Curitiba, 9 jun. p. 23.

Turin, João (19-). A arte decorativa no Brasil. Curitiba: Casa João Turin. Manuscrito. 